\title{
Challenges of Manufacturing Sub-Sector to Compete in Foreign Markets: The Nigerian Experience
}

\author{
Sunday Ewah and Monica P. Lebo
}

\begin{abstract}
This research is an empirical work that focused on the challenges bedeviling the manufacturing sub-sector ability to produce products that can compete with other brands in foreign markets. The data for the study were generated from central bank of Nigeria (CBN) and world bank development indicator (WBDI) of various years. the ordinary least square (OLS) econometric technique was used on time series data of important variables of manufacturing output, trade openness and current account balance. to guide the study, it was hypothesized that institutional framework and government policy towards trade liberation encourages investment overtures. the findings of the study showed that trade openness and financial support significantly influence the performance of manufacturing sub-sector to produce goods for foreign markets even though the contribution of the Nigeria manufacturing sector is quite negligible. In conclusion the study recommended that the right investment induced policies and programmes should be put in place in order to ginger investment interest and supply both domestic and foreign markets with products that compete with other brands in the global markets.
\end{abstract}

Index Terms-Foreign Markets, Manufacturing, Products, Trade Openness.

\section{INTRODUCTION}

The manufacturing sector in contemporary economics has often been described as the engine room that propels growth and development strategies in domestic and foreign markets with satisfying goods and services. It is noted that the manufacturing output sub-sector is the major driver of economic growth in developing and developed countries, such that it requires nations that are lacking behind to key in the development process. The world market depends on industrialized nations for the supply of goods and services, especially automated machines and equipment and these nations gross national product (GNP) in terms of income generation has improve tremendously. In the international scene or global market, competition is intense as a result of new entrants and the Asian Tigers are almost gaining a reasonable share of the entire world market for useable products to the expense of earlier industrialized nations. The reason is that the manufacturing sector is the major determinant of the level of industrialization and real growth of any economy. For it plays a vital role in providing immediate inputs, finished goods, increasing foreign exchange earnings from international marketing, has positive spillover effects and create employment opportunities for aspiring companies and countries. But in the case of Nigeria manufacturing sector contribution on the

Published on September 17, 2019. average was a mere $4.19 \%$ to the nation's gross domestic product (GDP) in 2011. Nigeria with a population of about 200 million people, obviously is the biggest market in Africa, and ought to be a strong market for its manufacturing sector. It is important to note that when west African sub-region and other African markets are added, there will be a large existing market for quality products and services from Nigeria. Quite unfortunately, this has not been the case because the manufacturing sector has been operating under unfavourable conditions and environment. Therefore, the unimpressive performance of the manufacturing sector is self-made. For example, more than 270 firms were shot down/went into extinctions in 2016 due to lack of patronage of their products both in Nigeria and foreign markets, which resulted to retrenchment of workers and reduction in production for the few existing ones [1].

The past history of Nigeria's manufacturing and industrial development policies no doubt depicts a nation that has neglected development stride in that direction, due mostly to inconsistencies in economic policies, poor management strategies, institutional framework, infrastructural decay, weak technological base, some restrictions (instead of trade openness), poor sources of capital/foreign exchange malingering, deficit current account-balances, etc; to mention but a few issues. Definitely all these act as set back to firms and countries performances in the course of marketing locally or internationally.

However, Nigeria though endowed with material and human resources its manufacturing sub-sector and its match to join the league of industrialized national and compete in global sense/market is still be deviled with the above mentioned.

Hence the main objective of this study is to ascertain the extent to which the vulnerability of the business environment and institutional framework has affected manufacturing sub-sector's competitive advantage especially in foreign markets. To equally guide and direct the study, it is hypothesized that the vulnerable marketing environment and institutional framework affects manufacturers performance in foreign or international markets. Also government policy that favour trade openness, free entry and exit will encourage investors and the manufacturing sub-sector to engage in one or more investment overture. The operational variables are trade openness (To) and capital - current account balance (CAB) which are proxies for international trade while the dependent variable is manufacturing output (MOT). The remaining part of the research paper include; theoretical underpinning, Nigeria trade policies, challenges facing the manufacturing sector, reasons why it is difficult to compete in foreign markets, others include; Methodology adopted, 
model specification, Hypothesis, presentation and interpretation of result, conclusion and recommendations.

\section{THEORETICAL UNDERPINNING}

According to [2] manufacturing sector is viewed as the sector responsible for the production of merchandise for sale or use through the application of tools, machine, labour, chemical and biological formulation. It involves both handicraft of human activities and high tech through which raw materials are transformed or converted into finished products in large scale. In the view of [13] industrial development in the form of establishment of manufacturing industry to service consumers in various markets deals with the application of modern equipment, machines and technology in the production of goods and services as well as to alleviate human suffering and ensure welfare improvement in the society. Thus, contemporary manufacturing processes involve the development of managerial and entrepreneurial skills as well as high technological innovations that often promote large scale productivity and improve the provision and supply of goods and services to different markets (domestic and foreign markets) for different consumption and purchase purposes. Consequently, the growth in the manufacturing output subsector has been a basic factor in the recent successful transformation of most economies that have enjoyed unquantifiable increase in development stride and growth. [8] Revealed that there are some principal themes in any manufacturing sub- sector, which include; solution base high innovation, commitment to technology and innovation, which are the key for sustaining competitiveness and growth in the level of productivity in domestic and foreign markets. Similarly, this sector accelerates productivity and growth in which the spillover effects spread to other sectors of the economy. At the international scene and market its only countries and companies that turn out sophisticated products that command reasonable market share. The most recent examples being that of the newly industrializing countries (NICs) and their success in exporting manufactured products specially to emerging markets of Africa [1].

Thus various theories have been postulated to further describe the relationship that muster between manufacturing output and the proceeds that is often generated from domestic and foreign markets and translate to economic growth in an economy. The theories are briefly mentioned in this sections; kaldor growth laws, big push theory and variants of the endogenous growth theory [12]. Also [12] posited that the growth trajectory of developed economies in the post war era displayed the relationship between industrial and the performance of the marketing economy from a holistic perspective, and state that there is a close relationship between the growth of manufacturing output and the growth of gross domestic product (GDP). This law is specifically written as gGDP $\mathrm{a}_{0}+\mathrm{a}_{1} \mathrm{~g}$ MOT.

Where; GDP represents the growth of total output and gMOT is the growth of manufacturing output.

Note that the correlation existing within the two variables is not as a result of the fact that manufacturing output represents a vast component of total output. The regression coefficient is expected to be positive and less than unity.
This situation implies that the entire growth rate of the economy (both domestic and foreign trade) is associated with the excess of growth rate of manufacturing output subsector compared to the growth rate of non-manufacturing output. Suffice to say that high growth is usually associated with countries where the share of manufacturing industry contribution to both domestics and foreign markets is high and thus helps to improve such countries gross domestic product (GDP), [12].

\section{A. Big-Push Theory}

This theory was postulated by Rodenstin-Rodan in 1968 [19] that a comprehensive programme is necessary in form of a high minimum amount of investment to overcome the obstacles to development in an under developed economy and to launch it on the path of progress, which is to explore the manufacturing sub-sector and compete favourably with countries and firms in the world market. He further emphasized that to achieve successful industrialization of an underdeveloped economy requires a holistic and simultaneous approach, such as training of labour on skill acquisition, capacity building, provision of infrastructural facilities like good transport system, power and steel, telecommunication, etc, all these must be provided and developed. Furthermore, simultaneous approach as used by Rodan and others implies the development of other sectors of the economy, especially agriculture to promote both forward and backward linkages and the resultant effect will be balanced growth and development [11].

\section{B. Structural Change Theory}

This theory is premised on the notion that developing countries and their economic activities should pursue programmes that would transform their domestic economic structures from traditional subsistence agriculture-base to modern economic oriented-base as well as more urbanized and industrially diversified manufacturing sub-sector and be able to compete in the world market. The theory attempts to establish the relationship between manufacturing output and economic growth derived as a result of export of manufactured products proceeds in international markets. The theory further stressed that the under development of some countries, especially sub-saharan Africa is due to the underutilization and exploitation of their human and material resources, which emanated from institutional and structural failures and equally products of both international and domestic dualism. Consequently, the theory advocates structural transformations in lines with the description specified by [18]. According to these earlier mentioned scholars, the process of the transformation of underdeveloped economies should be pursued vigorously in such a manner that the contribution of the manufacturing sector to national income or gross national product (GNP) exceedingly surpases the share of the agricultural sector to the national revenue generation. The Lewis model's contribution to the structural change theory described underdeveloped economies from a two way perspective traditional economy, which involves over-populated rural subsistence sector with the surplus labour and market, and the other a highly productive modern sector in which the surplus labour force is transferred to work as skilled manpower [6] That means at the end there will be labour 
surplus workers transferred from the traditional sector that leads to manufacturing output, economic growth, and employment in the modern sector. Therefore, for development to occur, there is need to increase the contribution of the industrial sector to economic policies of nations, and [11] made us understand that the manufacturing sector plays a very crucial role in the economic development of developing countries.

\section{Nigeria Trade Policies Regimes ANd RECENT EXPECTATIONS}

Over the years Nigeria's trade policy has been somehow inconsistent with changes upon changes as the case prevails. But recent economic policy reforms have sought to drastically reduced the unpredictability of the trade policy regime, establish a schedule to fully adopt ECOWAS common external tariff and honour obligations under multilateral trading systems. A comprehensive recast of Nigeria's macroeconomic policies showed that we had the pre- and post -structural adjustment programme (SAP) trade policy regimes. During the pre- SAP period Nigeria economy was extremely dependent on oil export for foreign exchange, but the price of oil in the world market was equally not stable enough to generate the much desire revenue to engage in other sector of the economy- like manufacturing output, hence the severe shocks in the oil market created considerable balance of payment deficits. Despite import controls through import licensing, custom tariff, and outright ban which were the major instruments of trade policy, it failed to achieve industrialization. The post SAP trade policies witnessed considerable trade liberalization, principally motivated by the neo - liberal economic policies dictated by SAP. The major emphasis of the said period was to loosen controls, and allow the market forces of demand and supply to prevail in the allocation of foreign exchange and the direction of investment to productive sectors of the economy. The marketing boards that controls the marketing of agricultural products were scrapped and product exports became directly subjected to the dictates of the international commodity markets. Moreover, import licensing was banned, except during the short period of the dual foreign exchange regime in the mid1990s, foreign exchange demand was carried out through diverse market mechanisms, that include; SFEM, AFEM, IFEM etc. The effects of this action was the progressive devaluation of the home currency - Naira (\#), in bid to make imports expensive and thus discourage excessive importation of non-essential goods and services. To assist investors, the Nigeria Export Credit Guarantee and Insurance Corporation was established in 1988 and was later renamed Nigeria Export - Import Bank (NEXIM). It provided credit and risk bearing facilities to banks in order to enable them to support exports. This notwithstanding the pressure on balance of payment persisted, and was compounded by the debt service obligations but Nigeria got debt relief in 2005 through the effort of Paris club of creditors.

Presently, Nigeria has several incentives to propel her exports of both manufactured and agricultural products in international markets, but still prefer to use import prohibition of some products to protect its manufacturing and agricultural sectors. But then Nigeria businessmen and manufacturers in particular have made very insignificant use of the quantitative restrictions to their advantage. This is as a result of the fact that its production based is relatively weak, import dependent, and technologically deficient.

As indicated by the Nigeria Investment Promotion Commission (NIPC), the Nigerian economic and business climate permeat trade incentives aimed at encouraging existing manufacturers, exporters, etc. to increase and diversify the volume and value of non- oil exports from Nigeria to foreign markets.

Suffice to note that modern economic theory predicts that countries that adopt openness towards imbibing international marketing orientation benefits and enjoy higher growth rates than those that close their territorial boundaries or economies to international trade, [9], [13]

It is therefore imperative that openness without restrictions of an economy to world economies or international marketing brings unprecedented increases in financial and capital flow among participating countries and other changes that the interconnectivity possesses. The ability of countries having open door policies towards engaging in international marketing or foreign trade gives all the participating countries interdependence status and transfer of technological know-how from technologically developed countries to the less developed countries of subSaharan African, which Nigeria is one. This idea of course stimulates and culminates to an efficient and better productive capacity for domestic manufacturing industries [3]. Proponents of international trade are of the opinion that its openness has resulted to unprecedented increases in international trade in manufactured products and improved the economic wellbeing of participating countries because of the use of advance technology [14]. Therefore, it will be important for Nigeria to encourage its domestic manufacturing sector to boost its contribution in the world market and accrue the much needed foreign exchange that would propel development stride.

\section{Major Challenges Facing the Manufacturing SECTOR MARKET}

Abolo [1] listed the following as the current challenges facing the manufacturing sector market in Nigeria;

- Poor and deteriorating infrastructural Services.

- Deepening weak domestic demand for made in Nigeria goods.

- Unbridled influx of cheap imports of sub-standard fake and used products, and dumping of all manner of finished goods.

- Competition with sub-standard imports and illegally manufactured/uncertified local goods has led to the lack of competitiveness of made in Nigeria goods.

- Some imported alternatives, despite their poor quality, are cheaper and typically considered more appealing to consumers.

- Policy inconsistency and anomalies in custom duty.

- Cumbersome port administration that hinders the attainment of 48 hours' cargo clearing at the ports. 
- Crime and corruptions

- Multiple taxes and levies by the different tiers of government.

- Inadequate local source of raw materials for production, except imported.

- Over dependence on foreign machines, which sometimes are very expensive to afford.

- Relatively inadequate sources of funds to finance some of the manufacturing interest.

In summary, the effects of these challenges include the inability to compete globally and earn foreign exchange as expected and provide employment back home for the unemployed.

\section{ReAsons Why It Is Difficult to Complete in FOREIGN MARKETS}

Below is a continuum of reasons hindering the performance of the manufacturing sector to compete in foreign markets.

- Excessive regulatory compliance and traceability that act as draw back to business intentions.

- Slow rate of technology acquisition stemming from low investments in research and development.

- Inappropriate fiscal policy that act as disincentive to investment.

- High cost of funds arising from depreciation of the home currency (Naira) against major currencies coupled with high lending rates and extreme difficulties in accessing credit for working capital.

- Quality of products problem and infrastructural deficit.

- Dearth of qualified skilled manpower to handle some of equipments needed for production processes to turn out quality products for the world market.

\section{METhodology Adopted}

The study dependent solely on secondary data extracted from Publications of the Central Bank of Nigeria (CBN) and World Bank Development Indicator (WBDI). The analysis covered the period 1980 to 2015 , which is 35 years and the variables used include; manufacturing output-dependent variable, while trade openness (TO) and current account balance $(\mathrm{CAB})$ are independent variables and proxies for international trade. The econometric approach is ordinary least square (OLS) linear regression of time series data.

\section{Model SpecificAtion}

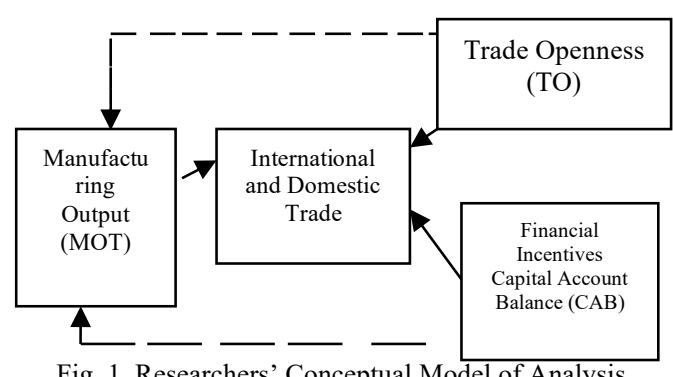

Fig. 1. Researchers' Conceptual Model of Analysis
Note: The broken lines represent the influence of trade openness and financial incentives enjoyed by manufacturing sector towards contributing to international and domestic products production and availability for consumption in the above markets.

\section{A. Hypothesis}

H1: Institutional framework, trade openness, and capital formation influence manufacturing sub-sector performance, especially in foreign markets.

The theoretical basis for this study is that the manufacturing sub-set is the main driver and determinant of the type and quality of output that will be produced and sold to emerging markets or international markets and the proceed that accrues used for development pursuit. Thus, Manufacturing Output (MOT) is a function of trade openness (TO) which represents export and import $((x-$ $M)$ and current account balance (CAB).

In a functional form it is represented as

$\mathrm{MOT}=\mathrm{F}(\mathrm{TO}, \mathrm{CAB})$

Applying ordinary least square (OLS) linear regression based on the above functional relationship implies:

$\mathrm{Yao}+\mathrm{b}_{1} \mathrm{x}_{1}+\mathrm{b}_{2} \mathrm{x}_{2}+\mathrm{u} \ldots \quad \ldots \quad \ldots$

Therefore "a" and " $u$ " in equation (2) represents the regression constant and the error term or stochastic error respectively.

Combining equation (1) and (2) gives the following:

$$
\mathrm{MOT}=\mathrm{F}\left(\mathrm{a}+\mathrm{b}_{1} \mathrm{TO}+\mathrm{b}_{2} \mathrm{CAB}+\mathrm{U}\right) \ldots
$$

Transforming equation (3) to the natural logarithm it will become:

$\log M O T=a o+b 1 \log T O+b 2 \log C A B$

Based on theoretical apriori, the following relationships are also expected among the variables under consideration.

$$
\frac{\delta \mathrm{TO}}{\delta \mathrm{MOT}}>0, \frac{\delta \mathrm{CAB}}{\delta \mathrm{MOT}}>0
$$

This implies whether represented by index of international trade openness or current account balance, it is expected that international trade exhibits positive relationship with manufacturing sub sector in output.

\section{PREsentation of DAta AND Interpretation of RESULTS}

The results of the analysis of data and interpretation of results are tabulated below;

TABLE I: RESULT OF REGRESSION ANALYSIS

\begin{tabular}{llll}
\hline \hline Variables & TO & CAB & C \\
\hline Coefficient & 0.295481 & 0.372062 & 24.98031 \\
\hline Standard Error & 0.008064 & 0.057954 & 0.185859 \\
\hline T. Statistic & -3.611594 & -0.642001 & -1.344043 \\
\hline Prob. & 0.0009 & 0.8033 & 0.0001 \\
\hline \hline
\end{tabular}

Source: Researchers' Computation 
Table I: The result clearly indicates that trade openness (TO) had a positive relationship with the level of manufacturing output (MOT) and it is evident based on the figure 0.295481 indicated. From this result it can be inferred that $1 \%$ increase in the rate of trade openness to emerging world market will generate a $0.29 \%$ increase in the growth of the manufacturing sub-sector. Furthermore $1 \%$ increase in current account balance (CAB) will result to a corresponding increase in the manufacturing sub-sector output to the tune of 0.372062 , representing $0.37 \%$.

\section{TABLE II: REGRESSION (LEAST SQUARE) STATISTICAL RESULTS}

\begin{tabular}{ll}
\hline Squared & 0.993024 \\
Adj .R. Squared & 0.991474 \\
S.E of Regression & 151896.5 \\
Sum Squared Resid & $6.23 \mathrm{E}+11$ \\
Log Likelihood & -449.9772 \\
Durbin- Watson Stat. & 1.600306 \\
Mean dependent var. & 738970.4 \\
S.D. dependent var. & 1645011 \\
Akaike info criterion & 26.88101 \\
Schwarz criterion & 27.19526 \\
F. Statistics & 64.05756 \\
Prob.(F-Statistic) & 0.000000 \\
\hline \hline
\end{tabular}

Source: Researchers' Computation

Table II result also shows that adjusted $\mathrm{R}^{2}$ figured was given as 0.991474 which invariably represent $99 \%$ and Durbin-Watson statistic was 1.600306 figures. The high $\mathrm{R}^{2}$ indicated that the variation stands to explain each other to a great extent, hence both variables of $\mathrm{TO}$ and $\mathrm{CAB}$ explained about $99 \%$ systematic variations on the rate of the manufacturing output growth rate, within the period under review. This analysis implies that both variables which are proxies for international trade have positive relationship with the manufacturing sub-sector output in Nigeria.

\section{CONCLUSION AND RECOMMENDATIONS}

The findings of the study conformed with the earlier assertions of [15], [9], [10] and [13], on open stances towards embracing international trade and further justified that trade openness permeates unprecedented increase in financial and capital flow amongst participation countries [3], also opined that international trade inspired the manufacturing sector to produce goods to boost economic prosperity of nations and create avenues for revenue generations to improve GNP.

In conclusion the government need to have a rethink and evolve realistic and pragmatic strategies for the development and sustainability of the manufacturing sector in Nigeria to enhance domestic and foreign markets consumption, which will in turn attract revenue for further investment overtures. Most contemporary economies encourage openness in trade deals and implore policies that favour trade liberalization to boost the world markets for consumption of goods and services. Therefore, the entire business climate in Nigeria must create a demand driven and responsive business model that provides flexibility and agility to respond to increase demand market disruptions. The study therefore recommends that the government should introduce and implement the right investment induced policies and programmes that will spur individuals and organizations interest towards investing in the manufacturing sub-sector.
TABLE III: COMPRISES FIGURES OF THE DIFFERENT YEARS USED FOR THE

\begin{tabular}{llll}
\multicolumn{3}{l}{ STUDY } \\
\hline \hline YEAR & MOT & TO & CAB \\
\hline 1980 & 1.024 .000 & 0.469096 & 13057.9 \\
\hline 1981 & 1.174 .000 & 0.501114 & 10070.3 \\
\hline 1982 & 1.328 .000 & 0.386737 & 7980.9 \\
\hline 1983 & 948.000 & 0.308925 & 6752.3 \\
\hline 1984 & 834.000 & 0.272822 & 8234.3 \\
\hline 1985 & 1.000 .000 & 0.276594 & 10738.9 \\
\hline 1986 & 961.000 & 0.215544 & 8006.6 \\
\hline 1987 & 1.284 .000 & 0.458287 & 17138.2 \\
\hline 1988 & 1.352 .000 & 0.378440 & 31586.1 \\
\hline 1989 & 1.543 .000 & 0.409744 & 59112 \\
\hline 1990 & 1.629 .000 & 0.581588 & 79810.1 \\
\hline 1991 & 1.781 .000 & 0.676055 & 51969.8 \\
\hline 1992 & 1.692 .000 & 0.654132 & 93680.5 \\
\hline 1993 & 1.452 .500 & 0.562095 & 34414.7 \\
\hline 1995 & 1.442 .000 & 0.409893 & 52304.3 \\
\hline 1996 & 1.362 .000 & 0.856301 & 188084.8 \\
\hline 1997 & 1.387 .000 & 0.692699 & 240180 \\
\hline 1998 & 1.385 .000 & 0.744968 & 268809.4 \\
\hline 1999 & 1.331 .000 & 0.586788 & 331436.2 \\
\hline 2000 & 1.337 .000 & 0.642289 & 46336.2 \\
\hline 2001 & 1.382 .000 & 0.645874 & 713023.9 \\
\hline 2002 & 1.422 .000 & 0.688475 & 108996 \\
\hline 2003 & 1.463 .000 & 0.603159 & 117037.3 \\
\hline 2004 & 1.480 .000 & 0.743848 & 704560 \\
\hline 2005 & 1.457 .000 & 0.577495 & 2056320.3 \\
\hline 2006 & 1.458 .000 & 0.687665 & 4891744.47 \\
\hline 2007 & 1.459 .000 & 0.578351 & 4357587.19 \\
\hline 2008 & 1.502 .900 & 0.605213 & 3879226.21 \\
\hline 2009 & 1.513 .100 & 0.666716 & 3748346.62 \\
\hline 2010 & 1.478 .000 & 0.626045 & 3408108.60 \\
\hline 2011 & 1.467 .000 & 0.614120 & 3320621.20 \\
\hline 2012 & 1.475 .000 & 0.62700 & 3212000.30 \\
\hline 2013 & 1.458 .000 & 0.645210 & 2984560.40 \\
\hline 2014 & 1.454 .500 & 0.64400 & 2792340.7 \\
\hline 2015 & 1.446 .000 & 0.656330 & 2844011.10 \\
\hline \hline & 1.436 .200 & 0.654400 & 2502310.8 \\
\hline & & \\
\hline & & & \\
\hline & & &
\end{tabular}

Source: Researchers' Compilation from CBN Statistical Bulletin of Various Issues and World Bank Development Indicator (WBDI)

\section{REFERENCES}

[1] Abolo, E. M. Overcoming the challenges of the Manufacturing Sector in Nigeria. MAN Federal Ministry of Industry, Trade and Investment, 2017.

[2] Adofu, 1. Taiga, U. U. and Tijani, Y Manufacturing Sector and Economic Growth in Nigeria. Donnish Journal of Economics and International Finance, Vol. 1, No;1, Pp.1-6, 2015.

[3] Akinmulegun, S. O. (2011). Globalization, FDI and Economic Growth in Nigeria, 1986-2009. An unpublished PhD Thesis.

[4] CBN. Central Bank of Nigeria Statistical Bulletin, Abuja, 2011.

[5] Chukwuedo, S.O. and Ifere, E.O. Manufacturing Sub-sector and Economic Growth in Nigeria. British Journal of Economics, Management and Trade, Vol.17, No.3, Pp.1-9, 2017.

[6] Dauda, R.O.S The Determinant of Manufacturing Sector Growth performance in Nigeria. Nigeria Journal of Economic and Social Studies, vol.5, No.1, 2013.

[7] Emilia, H. The Importance of the Manufacturing Sector in the Romanian Economy. 9 $^{\text {th }}$ International Conference Interdisciplinary in Engineering. Procedia Technology, Vol.22, Pp. 976-983, 2016.

[8] Emmanuel, O.O. and Saliu, W.D. Hards of Manufacturing Sector and Economic Growth in Nigeria. IJSSHE-International Journal of Social Sciences, Humanities and Education, Vol.1, No:1, Pp. 1-6, 2017.

[9] Frankel, J.A. and Romer, D. (1991) Does Trade Cause Growth? America Economic Review, Vol.89, No.3, June. Pp: 379-399, 1991.

[10] Hill, C.W. Global Business Today. Mc Growth Hill/Irwin, $3^{\text {rd }}$ Ed. New York, 2004.

[11] Jhinghan, M.L. Economics of Development and planning. Delhi, Vrinda Publications limited, 2011

[12] Libanio, G. Manufacturing Industry and Economic Growth in Latin American: A kaldorian Approach. CEDEPLAR, Brazil: Federal University of Minas Gerais, 2006 
[13] Obadan, M.I Globalization: Concepts, Opportunities, and Challenges for Nigeria Development. Text of a papper Presented at the Training programme on Economic Reform, 2010

[14] Sachs, J. D. The end of Poverty. The Penguin Press, New York, 2005.

[15] Sachs J.D and Warner, A. Economic reform and the Process of Global Integration. Brooking Papers on Economic Activity. Vol.1, Pp.-196, 1995.

[16] Simbo, A. B., Iwuji, I. I., and Bagshow, K. 2012. The Performance of the Nigeria Manufacturing Sector: A 52 years Analysis of Growth and Regression (1960-2012). Asian Economic and Social Society, Vol.2, No. 8, Pp. 177-191, 2012.

[17] The World Bank 2012), World Bank Development Indicators. Washington D.C, 2012.

[18] Todaro, M.P. and Smith, S.C. Economic Development, $11^{\text {th }}$ Edition, Edinburgh, Pearson Education Limited, 2011.

[19] WEF. The Determinant of Manufacturing Sector Adds Value to Economic Growth and Creates Job, Press Trust Ltd. India, 2013.

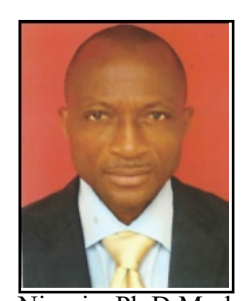

Dr. Sunday Ewah was born on the 20th of October 1968 and hail from kakwagom Irruan in Boki Local Government Area of Cross River State, Nigeria. The author's educational qualifications include,

First degree, University of Uyo Nigeria, BSc Marketing 1994

Second degree, University of Calabar, Nigeria, MBA with thesis, Specialization in Marketing2005

Third degree, Ebonyi State University Abakaliki,

\section{Nigeria, Ph.D Marketing 201}

$\mathrm{He}$ has been a season teacher for more than twenty-three years in Cross River University of Technology, Ogoja Camous, Nigeria.

The author has served as the HEAD of Business Administration Department, Cross River University of Technology from 2011-2016 and also served as the DEAN of Faculty of Management Sciences, Cross River University of Technology Between 2017-2019.

Presently the author lectures in the Undergraduate and postgraduate programme of the above mentioned University and also serves as visiting Associate professor of Marketing to two different University in Nigeria.

Dr. Sunday has reasonable numbers of publications in learned journals and a handful of textbooks to his credit. It is also important to mention that he presented two stimulating conference papers in London in 2013, and one in New Orleans, USA in 2014. The conference papers are stated below;

Ewah, S. Marketing Research as a Proactive Strategy for the Performance of Business; The Nigerian Experience. The Business Management Review, Vol. 4, No. 2, Pp, 164-177 London, UK, 2013

Ewah, S. and Lebo, M.P. Empirical Analysis of the Quality Dimension of a Product. The Business Management Review; Vol. 4, No.2, London, UK, Pp. 237-247; 2013

Ewah, S. The Challenges of Social Service Marketing in Nigeria. WEI International, Academic Conference Proceedings, New Orleans, USA. Pp. $62-74,2014$

$\mathrm{He}$ is a fellow of the National Institute of Marketing of Nigeria (NIMN) and Member, Institute of Industrialists and Corporate Administrators.

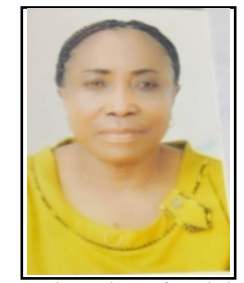

Monica P. Lebo was born on the 26th April, 1963 in Adadama, Abi Local Government Area of Cross River State, Nigeria.

Her educational qualification spread across three different Universities in Nigeria, which include;

BSc Secretarial Administration from River State University of Science and Technology, River State 1989

Postgraduate Diploma in Management, From the niversity of Calabar, Nigeria 2002

Master of Business Administration (MBA), from the University of Calabar, Nigeria 2008

Monica has taught in the then Polytechnic of Calabar for more than five years and later joined the services of Cross River University of Technology, Ogoja Campus in 2002. There she worked as a lecturer in the Department of Business Administration for more than six years. The author is currently teaching in the Department of Management, University of Calabar, Nigeria. She has published series of articles in learned journals and her zeal for education is unrelenting. To buttress this point, she recently defended her $\mathrm{Ph}$.D oral examination successfully. Two of her recent publications are listed below;

Lebo, M.P, Osakpa, D, U, Okonkwo, D.A and Ejiogu, S.I, Bus Skills Development Partnership and Women Empowerment for Accelerated Economic Growth in Africa Communities. Journal of Business Administration and Management Science Research. 161. 7, No.1 Pp. 1-19, June, 2018

Ewah, S. and Lebo, M.P Empirical Analysis of the Quality Dimension of a Product.

The Business Management Review; Vol. 4, No.2, London, UK, Pp. 237$247 ; 2013$. 